\section{Pre-service Teacher Perceptions in Integrating Maker-Centered Learning in their Mathematics and Education Initial Teacher Education Programme}

UTE. Revista de Ciències de l'Educació

Monogràfic 2020. Pag. 50-67

ISSN 1135-1438. EISSN 2385-4731

http://revistes.publicacionsurv.cat/index.php/ute

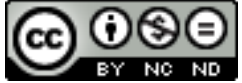

https://doi.org/10.17345/ute.2020.4.2778

\author{
Cornelia Connolly $\mathbb{D}^{D}$, Sean 0 Gorman, Tony Hall, Raquel Hijón-Neira \\ Rebut: 29/03/2020 Acceptat: 27/04/2020
}

\begin{abstract}
This paper describes an innovative programme ' $\mathrm{C}^{2} 4 \mathrm{M}^{2}$ : Creative Coding for Math's Makers', in an undergraduate concurrent teacher education degree programme. Using the Makerspace in a University setting, the programme fostered a culture of creativity and innovation through combining mathematics and the more widely recognized STEM subjects. In addressing the challenge of preparing teachers effectively to teach key STEM areas, such as computational thinking, in an engaging and effective way, this paper describes a maker-design and structure, integrating physics with computer coding, to address the challenge in preparing student teachers of mathematics. The paper aims to validate and explore the pre-service teachers' perceptions of computer science and demonstrates the potential of maker-centred learning as a powerful context for promoting and enhancing STEM education, both amongst pupils and pre-service teachers. This paper examines if the design of the C24M2 fosters a positive attitude towards computing for this set of pre-service teachers. The research conducted addresses the salient issues in sustaining and integrating maker-centred learning more widely and systematically within education, particularly the need to support teacher professional development in maker-centred learning to mediate sustainable, high impact learning in schools and other educational settings.
\end{abstract}

Keywords: Teacher Education, Coding, Computational Thinking.

\title{
Resumen
}

Este trabajo presenta el programa innovador " $\mathrm{C}^{2} 4 \mathrm{M}^{2}$ : Creative Coding for Math's Makers" (Codificación creativa para creadores matemáticos), en el contexto de una titulación de grado para la formación de docentes. Utilizando el concepto de Makerspace en un entorno universitario, el programa fomentó una cultura de creatividad e innovación mediante la combinación de matemáticas y las materias STEM. Al abordar el desafío de preparar a los maestros de manera efectiva para enseñar áreas clave de STEM como el pensamiento computacional- de una manera atractiva que enganche a los estudiantes, este documento describe un diseño y una estructura "maker", o lo que es lo mismo, que integra aspectos físicos con programación de ordenadores, para abordar el desafío de preparar a los futuros docentes del área de matemáticas. Este trabajo tiene como objetivo explorar y validar las percepciones que tienen el profesorado en formación acerca de la informática, y demostrar el potencial que tiene una aproximación maker al aprendizaje, en tanto que contexto idóneo para promover y mejorar la educación 
STEM, tanto entre el alumnado como entre el profesorado en formación. Este artículo examina si el diseño del $\mathrm{C}^{2} 4 \mathrm{M}^{2}$ fomenta una actitud positiva hacia lo digital en este grupo de profesores en formación. Además, la investigación realizada aborda los problemas más importantes para mantener e integrar el aprendizaje maker de manera más amplia y sistemática dentro de la educación; particularmente explora la necesidad de apoyar el desarrollo profesional de los docentes en este tipo de aprendizaje, para mediar procesos de aprendizaje sostenible y de alto impacto, tanto dentro de las escuelas como en otros entornos educativos.

Palabras Clave: Formación del profesorado, Programación, Pensamiento computacional.

\section{Introduction}

In his seminal work 'The Process of Education' Bruner wrote "If it cannot change, move, perturb, inform teachers, it will have no effect on those they teach. It must first and foremost be a curriculum for teachers. If it has any effect on pupils, it will have it by virtue of having effect on teachers." (Bruner, 1996, p. xv). This philosophy underpins the innovative programme ' $C^{2} 4 \mathrm{M}^{2}$ : Creative Coding for Math's Makers' as an approach to increase awareness and improve perceptions of computer science education and computational thinking teaching and learning opportunities amongst pre-service teachers of mathematics.

This project is particularly timely as a national Computer Science curriculum is being introduced to all schools. The introduction of Computer Science (CS) at Senior Cycle, along with the introduction of coding at primary level will change the way schools in this jurisdiction approach computing and information technology - replacing the idea of IT literacy and passive consumers of computing with innovators, creators and designers. The Senior Cycle Computer Science curriculum supports the use of a wide range of teaching and learning approaches to encourage students develop the knowledge, skills, attitudes, and values that will enable them to become independent learners and develop a lifelong commitment to improving their learning. However, while there is currently significant investment by government and the development of a curriculum for Computer Science, the teacher education piece of the provision remains largely underdeveloped.

The engagement of teachers in computer science and computational thinking (CT) professional development - especially through innovative, high-potential approaches, such as makerspace - has by contrast been problematically overlooked. The Creative Coding for Math's Makers programme therefore - although at a formative and incipient stage in its development - helps to address this gap, demonstrating key findings to guide and inform future research and the design of teacher PD. The programme also fostered and enabled a partnership with schools in the city and region, and therefore enhancing the schoolchildren's experience of computing and computational thinking. Positive transformations of computational thinking and computing concepts in the makerspace is a hopeful outcome of this programme. Developing a mindset of positivity, perseverance and practicality were concepts underpinning the design of the Creative Coding for Math's Makers programme and which also align with those of Makerspace (Martin, 2015).

This paper is organized into six sections. The first section, after the Introduction, gives an overview of the related literature, briefly exploring computational thinking, mathematical thinking and computational thinking integration in pre-service teacher education. The third section analyses the context of the research, the Makerspace facility and those who participated in the study. In the fourth section the methodology is presented, the framework, timeline and the data gathering process. The results are presented in the fifth section and our conclusions are drawn in the final section of the paper. 


\section{Literature Review}

In Ireland currently, just over twenty years since the publication of the first official policy document for educational technology in schools (DES, 1997), there are exciting developments happening in the space of syllabus and system change to give a proper, official status of Computer Science education and computational thinking in the state-approved Irish school curriculum. The syllabus is now extant, and the government is matching this seminal and historic development with substantial public funding.

Ensuring teacher education programmes support the development of pre-service teachers to achieve the goal of creative and engaging CS education is imperative, and Ireland is very much in the formative stages of conceptualizing and designing teacher education in this space. The research reported here is at the frontier in exploring how teacher education in computational thinking might be best designed and deployed within the Irish educational system.

The aim of " $\mathrm{C}^{2} 4 \mathrm{M}^{2}$ : Creative Coding for Math's Makers" was to integrate mathematical and programming concepts, with a specific focus on encouraging computational thinking amongst our student teachers. The participants of the programme were students of the Bachelor of Arts, Mathematics and Education (BME) programme at the University - an undergraduate concurrent initial teacher education degree programme. This BA Mathematics and Education programme qualifies teachers at post-primary level in mathematics and applied mathematics, who are also fully qualified mathematicians. The aim in introducing computational thinking concepts in a maker-designed initiative for the pre-service teachers forms valued insight and exposes the student teachers to the discipline of Computer Science and develops cross curricular thinking.

\subsection{Computational Thinking}

From the beginning in the mid 60's, in Computer Science, the emphasis in teaching was put on algorithms and algorithmic thinking as the main components. Algorithmic problem solving was the term given to the systematic development of a computer solution for a problem, covering the entire process of designing and implementation. A much wider view on computing competencies was then proposed by Jeannette Wing in her seminal work on computational thinking (Wing, 2006) - which extends algorithmic thinking and fluency in working with information technology to competencies which are built "on the power and limits of computing processes, whether they are executed by a human or by a machine."

$\mathrm{CT}$ is a fundamental skill useful for diverse subjects and can be promoted through various approaches and tools. Computational thinking (CT) uses cognitive processes that are useful across school subjects and also in the real world, where problems are often ill defined (Cuny et al., 2010). Proposed by Jeannette Wing in her seminal work on computational thinking (Wing, 2006), computational thinking extends algorithmic thinking and fluency in working with information technology to competencies which are built "on the power and limits of computing processes, whether they are executed by a human or by a machine" (Wing, 2006). In regard to conceptual development, Computational thinking, is required to engage in decomposition of the problem, activities such as abstraction, algorithmic design, debugging, iteration, and generalization.

Resnick and Robinson emphasized the importance of learners developing as computational creators (Resnick \& Robinson, 2017) and found that computational fluency involves not only an understanding of computational concepts and problem-solving strategies, but also the ability to create and embed digital technologies. Computational fluency benefits learners as well as educators and in a rapidly globalizing world where these are skills will help citizens understand and appreciate more their geographical, social, cultural and economic contexts (Resnick \& Robinson, 2017). 


\subsection{Mathematical Thinking}

Mathematics fundamentally hones the power of reasoning and problem solving. In technology-rich mathematics education, mathematics teachers experience related challenges in fostering mathematical and computational thinking evidenced in the revised curricula and curriculum reform. The framework used by PISA shows that mathematical literacy involves many components of mathematical thinking, including reasoning, modelling and making connections between ideas (PISA, 2006). Therefore, mathematical thinking is vital because it equips students with the ability to use mathematics. NRICH declares "Exploring, questioning, working systematically, visualizing, conjecturing, explaining, generalizing, justifying, proving... are all at the heart of mathematical thinking" (NRICH, 2019). Mathematical thinking involves the application of math skills to solve math problems, such as equations and functions (Sneider et al., 2014). One can think mathematically and learn to think mathematically (Mason et al., 2011). It is provoked by contradiction, tension and surprise and supported by an atmosphere of questioning, challenging and reflecting. Importantly Mathematical Thinking helps in understanding oneself and the world (Mason et al., 2011).

Mathematics is closely linked to Computational Thinking as it involves pattern recognition of problem structures and variables that can be instantiated with different values, such as decomposition, to enable modularity and easier problem-solving; algorithm design, due to its emphasis on logical reasoning and generalization, i.e. from multiple examples to formulation of principles. Weintrop et al. (2016) explored the benefit of $C T$ in mathematics "The thoughtful use of computational tools and skillsets can deepen learning of mathematics and science content" (Weintrop et al., 2016)

\subsection{Computational Thinking in Teacher Education}

In order for computational thinking to be part of every student's education, initial teacher education programmes at University should include a class on computational thinking across the disciplines (Barr \& Stephenson, 2011).

In many countries the focus of computer science education at post-primary level has shifted from computer and ICT applications towards a more rigorous academic discipline (Bell et al., 2010; Brown et al., 2013; Hubwieser, 2012). The alternative for countries still to adopt a national CS curriculum has resulted in the integration of computational thinking in pre-service teacher education, which has been varied and different. Aligned to this, the literature on embedding computational thinking in pre-service teacher programmes and ultimately in their future classrooms has been somewhat limited (Yadav et al., 2014).

A study by Prieto-Rodriguez and Berretta focused on the students thinking about the nature of computer science and whether their perceptions about computer science change after such a workshop (Prietorodriguez \& Berretta, 2014). Their results demonstrated that there is positive impact on pre-service teacher skills regarding perceptions of computer science, when they are connected to the skills and resources needed to teach computer science and computational thinking concepts.

Yadav et al. (2014) introduced pre-service teachers to computational thinking through a one-week module in an introductory educational psychology course and then explored how to embed computational thinking in the K-12 classroom (Yadav et al., 2014). In examining the effectiveness of the module on preservice teacher's definition of computational thinking as well as the student teacher ability to embed CT in future classrooms, the results suggested that pre-service teachers who were exposed to the modules were significantly more likely to accurately define computational thinking. Results also demonstrated that the pre-service teachers were more likely to agree with $C T$ being implemented in classrooms by allowing students to problem-solve in a plugged and unplugged environment. 


\section{Context of Study}

Ní Ríordáin and Hannigan published a report in 2009 concluding that $48 \%$ of the 324 mathematics teachers in Ireland surveyed did not have a mathematics teaching qualification (Ní Ríordáin \& Hannigan, 2009). Further research suggested that teachers were "assigned by school administrators to teach subjects which do not match their training or education" (Ní Ríordáin \& Hannigan, 2011). At the time of its introduction, this concurrent initial teacher education degree programme represented the first and only teacher education degree programme to focus in such a deep and specialized manner on the mathematical sciences. The BA Mathematics and Education programme was designed to address the identified need in Irish education for excellent teachers of Mathematics and Applied Mathematics in schools. The programme has now for almost a decade made a very significant contribution - at source - to the stream of new mathematics teachers entering the profession in Ireland every year. As well as secondary teachers recognized by the Teaching Council, graduates of the BA Mathematics and Education are highly qualified mathematicians, educated beyond the requirements of the Leaving Certificate Honors Level Mathematics/Applied Mathematics.

The rationale for introducing computational thinking development and computer science concepts as an addition to the BA Mathematics and Education students, is to address recent educational developments, specifically the introduction of the Computer Science Senior Cycle curriculum and to harness the close conceptual relationship between Computer Science and Mathematics. It is therefore timely to consider the integration of computing concepts within the BA Mathematics and Education model and enhancing the pre-service teacher's education.

\subsection{The Makerspace Facility}

The importance of the social setting to cultivate and to engage in higher order thinking and problemsolving cannot be stressed enough (Resinck, 1987). The need for a productive learning environment that is safe and orderly is one of the most consistent findings in educational research (Doyle, 1986; Emmer et al., 2003; Evertson et al., 2003).

The library at the university provides a Makerspace facility accessible to students, fostering a culture of creativity and innovation. Such exposure and experience is of value to pre-service teachers as it replicates life in a STEM industry and exposes them to technologies and tools which facilitate collaborative learning, essential to encourage creativity, problem solving and critical thinking. Makerspaces offer the potential for educational reform and the collaborative nature of the sessions is in line with literature on effective practices for professional development (Kennedy, 1999). Creating makerspaces for learning and invention can help students grow and subsequently enhance their potential. The ability to utilize tools and develop new skills to create objects (products) is important for the twenty first century learner and a valued skill (DES, 2016; NCCA, 2009, 2017).

\subsection{Participants}

The pre-service student teachers who participated in the $\mathrm{C}^{2} 4 \mathrm{M}^{2}$ : Creative Coding for Math's Makers were volunteers. While using volunteers may skew a sample towards those who are naturally more confident, motivated, able, focused and assertive (Cohen et al., 2000), this was deemed most suitable. There are undoubtedly gains for the students in taking part in this type of research, which may not be immediately apparent, but students coerced into participation would not be likely to contribute a genuine picture of their views and computational competencies. Furthermore, this would be a purposive sample to enable the researchers to gain a first insight into how maker-centered education could be designed within teacher education more broadly in Ireland. 
A choice with regard to the size of the group was "...struck between the group being too small for interactive study or too large thus preventing all group members from participating in the discussion" (Ginsburg, 1981). In this case it was decided to ask all the class participate, and all pre-service student teachers in their third year of a four-year degree programme participated. All students were pre-service teachers, completing the BA Mathematics and Education programme.

\section{Research Design}

The design of the $C^{2} 4 \mathrm{M}^{2}$ : Creative Coding for Math's Makers programme addresses a key challenge for mathematics and computing and ultimately education in Ireland. The introduction of coding in schools and the new Computer Science Leaving Certificate present a landmark opportunity for STEM advancement in Ireland; however, there is the challenge now to prepare teachers properly to teach these key STEM areas in an engaging and effective way.

The research questions being addressed in this research are: Can preservice teachers improve their computing attitude after completing Creative Coding for Math's Makers? Can preservice teachers improve their efficacy by using $\mathrm{C}^{2} 4 \mathrm{M}^{2}$ ? Can preservice teachers improve their Mindset upon completion of Creative Coding for Math's Makers?

The research was broken into three identifiable phases, as shown in Figure 1. The Exploratory Phase of the research was initiated at the start of the academic year and consisted of a detailed, systematic literature review, concentrating on the areas of higher education and Makerspace in initial teacher education, with specific emphasis on computer science. This provided a context from the analysis of learning strategies, constructivism, educational design and facilitating computational thinking for mathematics students in a Maker environment and thus the Creative Coding for Math's Makers programme. The data collection and evaluation were conducted after the evaluation cycle. Following this collection, reflection and discussion on the programme was conducted.

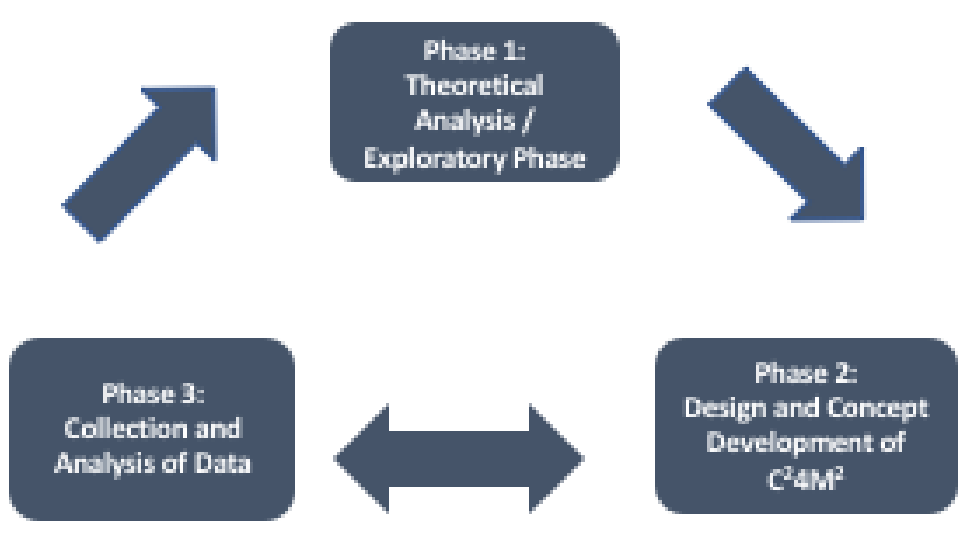

\section{$4.1 C^{2} 4 M^{2}$ Structure}

Figure 1: High level overview of reserach structure for $C^{2} 4 M^{2}$

The timescale for this study was designed to accommodate the pre-service teacher semester and their academic framework. Research demonstrates how to incorporate computational thinking into classrooms and the evidence shows that project-based approaches are the best path to fluency across many disciplines (Csizmadia et al., 2015; Curzon \& McOwan, 2017; NRC, 2010; Resnick \& Robinson, 2017; 
Yadav et al., 2017). The $\mathrm{C}^{2} 4 \mathrm{M}^{2}$ programme therefore was incorporated into the semester and academic module structure, therefore the pre-service teacher students did not have to attend additional classes, as shown in Table 1. The programme structure was originally planned for eight weeks, however due to external timetabling challenged the programme was reduced to seven weeks.

The first week involved the pre-service teachers being introduced to the technology. In this first week it was envisaged that the third-year cohort of pre-service teachers would experience the Makerspace as if they were students. Their experiences and perceptions as makerspace learners and makerspace teachers would be valuable. In the second week of the programme, the students were allocated into groups to research, develop and design two activity-based lessons using the Makerspace facilities. The following week the class visited the onsite University Computer Museum to contextualize the technology evolution and understand more fully how computing and technology has advanced. During the next week, week 5 of semester, the third-year pre-service teachers conducted this Makerspace lessons to their more junior colleagues in first and second year of the same degree programme. This lesson gave the students the opportunity to practice their lesson, again to review their experiences as makerspace learners, and makerspace teachers. During the fifth and sixth classes of the $\mathrm{C}^{2} 4 \mathrm{M}^{2}$ programme, students from a local primary school were invited to attend. These school children were divided into groups for the two-hour session. During the last three sessions the pre-service teachers taught a slightly more advanced lesson to post-primary school children. The school invited were from a local primary school, an all-girls school who had very limited experience to technology or a Makerspace environment prior to this project.

Table 1: Outline for C24M2, Creative Coding for Maths Makers

\begin{tabular}{|c|c|c|c|c|c|}
\hline Semester & $C^{2} 4 M^{2}$ & Activity & Duration & Participants & Date \\
\hline Week 3 & 1st class & $\begin{array}{l}\text { 3BME students are introduced to the } \\
\text { technology equipment and scope of the } \\
\text { facilities at the MakerSpace }\end{array}$ & $2 \mathrm{hrs}$ & 3BME & $\begin{array}{l}\text { Fri. Feb. } \\
\text { 2nd }\end{array}$ \\
\hline Week 4 & 2nd class & $\begin{array}{l}\text { Student teachers will be allocated in } \\
\text { groups to research, develop and design } \\
\text { tow activity-based lessons using the } \\
\text { MakerSpace facilities }\end{array}$ & $2 \mathrm{hrs}$ & 3BME & $\begin{array}{l}\text { Fri. Feb. } \\
\text { 9th }\end{array}$ \\
\hline Week 5 & 3rd class & Student visit the computer museum & $2 \mathrm{hrs}$ & 3BME & $\begin{array}{l}\text { Wed. Feb. } \\
\text { 14th }\end{array}$ \\
\hline Week 5 & 4th class & $\begin{array}{l}\text { The 3BME students teach both of their } \\
\text { MakerSpace lessons to other } \\
\text { undergraduate students }\end{array}$ & $3 \mathrm{hrs}$ & 2BME, 1BME & $\begin{array}{l}\text { Fri. Feb. } \\
\text { 16th }\end{array}$ \\
\hline Week 6 & 5th class & Delivery of Lesson 1 - Primary & $2 \mathrm{hrs}$ & $\begin{array}{l}\text { Primary } \\
\text { school } \\
\text { children }\end{array}$ & $\begin{array}{l}\text { Fri. Feb. } \\
23 r d\end{array}$ \\
\hline Week 7 & 6th class & Delivery of Lesson 2 - Primary & $2 \mathrm{hrs}$ & $\begin{array}{l}\text { Primary } \\
\text { school } \\
\text { children }\end{array}$ & $\begin{array}{l}\text { Fri. March } \\
\text { 9th }\end{array}$ \\
\hline Week 7 & 7th class & Delivery of Lesson 1 - Secondary & $2 \mathrm{hrs}$ & $\begin{array}{l}\text { Secondary } \\
\text { school } \\
\text { children }\end{array}$ & $\begin{array}{l}\text { Fri. March } \\
\text { 9th }\end{array}$ \\
\hline Week 8 & 8th class & Delivery of Lesson 2 - Secondary & $2 \mathrm{hrs}$ & $\begin{array}{l}\text { Secondary } \\
\text { school } \\
\text { children }\end{array}$ & $\begin{array}{l}\text { Tues. } \\
\text { March } \\
\text { 13th }\end{array}$ \\
\hline Week 8 & 9th class & Delivery of Lesson 3 - Secondary & $2 \mathrm{hrs}$ & $\begin{array}{l}\text { Secondary } \\
\text { school } \\
\text { children }\end{array}$ & $\begin{array}{l}\text { Wed. } \\
\text { March } \\
\text { 14th }\end{array}$ \\
\hline
\end{tabular}




\subsection{Data Gathering}

A questionnaire method was chosen as the best way to accumulate data from the participants. The aim of the questionnaire administrated was to obtain information which could be analyzed, patterns extracted, and comparisons made regarding mindset, perceptions of computing attitudes, mindset and understanding of computer science. The main advantages to this form of research is that questionnaires are often more economical that other data generation methods.

In order to get a full picture of the pre-service teacher perceptions of computational thinking and computer, it is essential that opinions from the entire student cohort were examined. This relatively substantial amount of data can be generated for relatively low costs of materials and time when using questionnaires. The use of predefined answers (as in closed questions) makes questionnaires easy for respondents to complete and easy for researchers to analyze (Oates, 2006).

The Creative Coding for Math's Makers' questionnaire was developed to gather background information from the pre-service teachers. The evaluation tool used in this study was based on validated questionnaires, the Computer Anxiety and Learning Measure (CALM), fixed or growth mindset and Computing Attitudes Survey and the three areas were examined (Dweck, 2006; McInereny, 1997; Yadav et al., 2014).

The CALM model was developed using an abridged form of the original Computer Anxiety Rating Scale (CARS-R) and the Computer Thoughts Survey (CTS) both designed by Rosen, Sears and Weil, (Rosen et al., 1987). As computer anxiety is a situation-specific anxiety, it was felt that the integration of preexisting instruments relating to test anxiety were best to incorporated in the CALM model (Sarason, 1991; Spielberger, 1975a, 1975b). The teacher efficacy beliefs were measured with a modified version of the Teacher Efficacy Scale by Gibson and Dembo (1984). This measure consists of two factors: 1 ) teachers' beliefs in their personal teaching abilities to embed computational thinking, and 2) their general beliefs about the impact that teachers can have on student understanding of computational thinking (Gibson \& Dembo, 1984).

Based on the work by Carol Dweck, we explored the pre-service teachers' belief on whether they had a fixed and growth mindset (Dweck, 2006). In a fixed mindset, people believe their basic qualities, like their intelligence or talent, are simply fixed traits. In a growth mindset, people believe that their most basic abilities can be developed through dedication and hard work-brains and talent are just the starting point and this view creates a love of learning and a resilience that is essential in the Makerspace learning environment.

Thirdly, in order to examine preservice teachers' attitudes towards computing, we used the previously validated, Computing Attitudes Survey used to examine preservice teachers' understanding of CT, comfort and interest with $\mathrm{CT}$ and computer science, view of using computational thinking in their future classrooms, and view of how computational thinking will influence their future career (Yadav et al., 2014).

It has been regarded that reflection is a means to investigate practice and of theorizing about it (Schön, 1991). Schön distinguishes between 'reflection-in-action' involving for the most part situated knowledge as the practitioner struggles with the unfamiliar and 'reflection-on-action' requiring consideration of what the practitioner has done which he/she regards as fundamental to learning to teach. Schön encourages a reflective attitude in educationalists and expects them to investigate continuously their practice, which is an ongoing cycle and serves as a basis for professional development. It is necessary therefore for the pre-service teachers to think about the underlying explanations of the experience, reflect upon that experience and make an action plan for the future, in light of past experience. As with 
all pre-service teacher training our students competed lesson plans and reflections after each class and this qualitative feedback was invaluable.

The data collected allowed the researchers to observe a makerspace experience from multiple perspectives thereby, providing insight into the use of makerspaces for preservice teacher training and within the educational setting as a whole. The results from the questionnaire and the reflections are presented in the following section.

\section{Data Analysis and Discussion}

The third-year pre-service mathematics and applied mathematics teachers were surveyed prior to the Makerspace engagement and a post-questionnaire was administered at the end of the Creative Coding for Math's Makers seven-week experience. The questionnaire explored their Computer Anxiety and Learning Measure (CALM) (McInereny, 1997), their mindset (Dweck, 2006) along with their perceptions of Computer Science in the Computing Attitudes Survey, adapted from Yadav et al. (2014). The student reflections of the programme were also gathered and qualitative answers analyzed.

This section presents data indicating the student teachers' perceptions of computing in regard to the Creative Coding for Math's Makers programme. The statistics present data gathered for students responding to each rating across the thirty items for the three sections in the questionnaire. The preand post-questionnaire results are presented in tabular form, quotes and boxplots. Boxplots are used to summarize information about the shape, dispersion, and center of the data and are useful in comparing the distribution of scores on variables.

Dicho cuestionario se ha enviado por correo electrónico en tres ocasiones (en abril, principios y finales de mayo 2018) a los 385 centros en los que se imparte Primer o Segundo Ciclo de Educación Infantil en Asturias, de acuerdo con la base de datos de la Consejería de Educación del Gobierno del Principado de Asturias (Educastur, 2018; https://www.educastur.es). En el segundo y tercer envío no se incluyeron los centros que ya habían respondido (aunque fuera para contestar que no iban a realizar la encuesta), para limitar las molestias para el personal docente.

\subsection{RQ1, Computing Attitude}

First, a descriptive analysis of the results obtained is shown. Table 2 shows the minimum, maximum value, the mean and the standard deviation of each test (pre and post). The results show that there are significant results in the results in the post-test. The minimum, maximum and mean values increase remarkably in the post-test results, although the dispersion increases.

Table 2: Means and Standard deviation computin attitude survey

\begin{tabular}{|c|c|c|c|c|}
\hline & $(n=5)$ & & & \\
\hline & Min & Max & Mean & SD \\
\hline 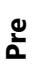 & 2,385 & 3,077 & 2,785 & 0,279 \\
\hline 苋 & 2,462 & 3,231 & 2,985 & 0,319 \\
\hline
\end{tabular}


Figure 2 shows the boxplots of the results in the evaluation of Computing Attitude in regard to the Creative Coding for Math's Makers programme in terms of pre- and post-test. Each box is delimited by the values Q1 (first quartile) and Q3 (third quartile). Each box groups $50 \%$ of the cases, highlighting the median. The lowest and highest value at the end of each diagram correspond to the values that are not less than $\mathrm{Q} 1-1.5 \cdot(\mathrm{Q} 3-\mathrm{Q} 1)$ and are not greater than $\mathrm{Q} 3+1.5 \cdot(\mathrm{Q} 3-\mathrm{Q} 1)$.

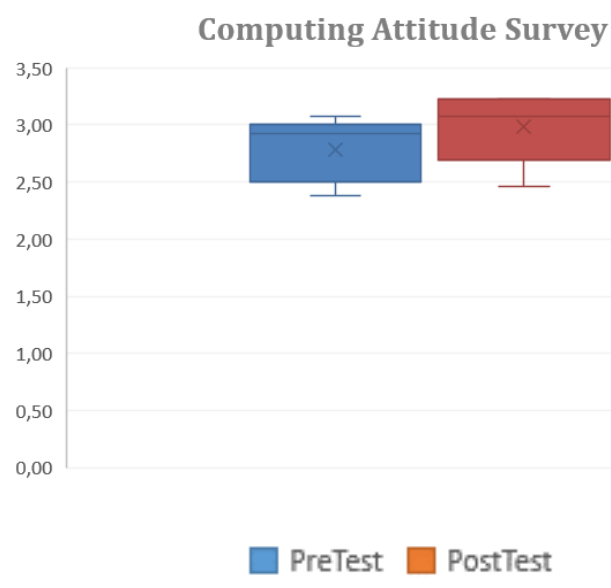

Figure 2. Boxblots for the group of students in pre and post-tests in Computing Attitude

Comparing the pre-test with the post-test, after analyzing the data, normality can be concluded for the study group (obtaining $p>0.05$ significance using the Shapiro-Wilk test), allowing us to use the tStudent test for paired samples ( $p>0.05$ using bivariate correlation tests). In this test, it has been assumed that the null hypothesis can be established, since there are no differences between the means. Therefore, a p-value greater than 0.05 will reveal homogeneity in the samples.

As a result, Table 3 shows the difference between the pre-test and the post-test in the Computing Attitude Survey and study. Therefore, it is deduced that the students had an improvement in the test scores when following the course planning $(p=0.240)$, although not significant. According to these results, the students achieved an improvement, although not significant in their computing attitude survey.

Table 3: Study using t-student and p-value analysis

\begin{tabular}{lll}
\hline & t test analysis & p-value \\
\hline Computing Attitude Survey & $-0,200$ & 0,240 \\
\hline
\end{tabular}

\subsection{RQ2, Efficacy}

First a descriptive analysis of the results obtained are shown. Table 4 shows the minimum, maximum values, the mean and standard deviation of each test (pre and post.) The results show that there are significant results in the results in the post-test. The minimum, maximum and mean values increase remarkably in the post-test results, in addition the dispersion decreases. 
Table 4: Mean and typical deviation in the Efficacy tests

\begin{tabular}{|c|c|c|c|c|}
\hline & \multicolumn{4}{|l|}{$(n=5)$} \\
\hline & Min & Max & Media & SD \\
\hline ఏ & 4,500 & 5,500 & 5,033 & 0,431 \\
\hline$\ddot{n}$ & 4.833 & 5,667 & 5,233 & 0,346 \\
\hline
\end{tabular}

Figure 3 shows the boxplots of the results in the evaluation of the pre- and post-test. Each box is delimited by the values Q1 (first quartile) and Q3 (third quartile). Each box groups $50 \%$ of the cases, highlighting the median. The lowest and highest value at the end of each diagram correspond to the values that are not less than $\mathrm{Q} 1-1.5 \cdot(\mathrm{Q} 3-\mathrm{Q} 1)$ and are not greater than $\mathrm{Q} 3+1.5 \cdot(\mathrm{Q} 3-\mathrm{Q} 1)$.

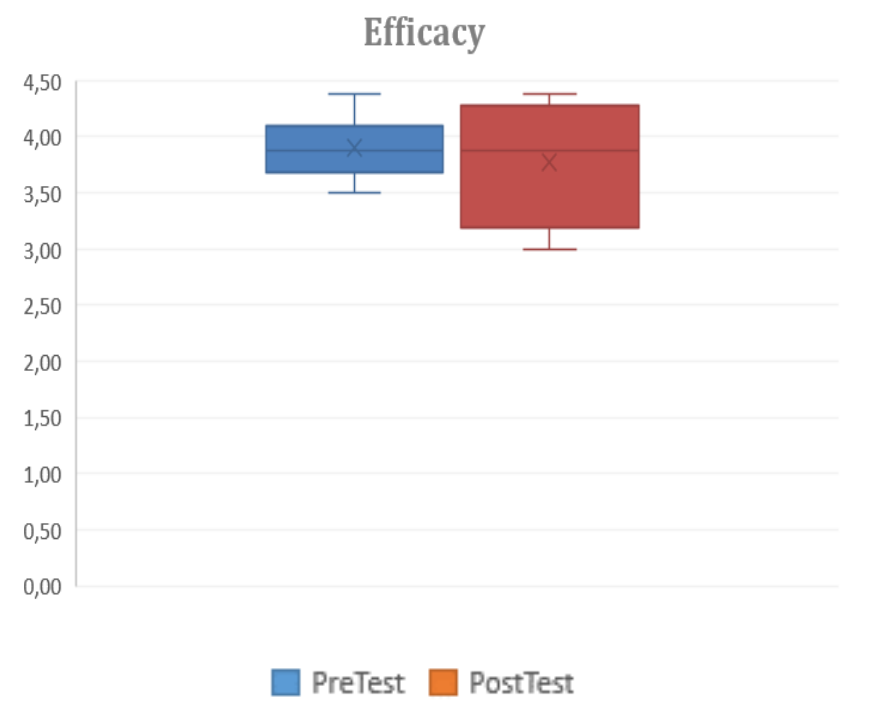

Figure 3. Boxplots for the group of students in pre and post-tests for Efficacy

Comparing the pre-test with the post-test, after analyzing the data, normality can be concluded for the study group (obtaining $p>0.05$ significance using the Shapiro-Wilk test), allowing us to use the tStudent test for paired samples ( $p>0.05$ using bivariate correlation tests). In this test, it has been assumed that the null hypothesis can be established, since there are no differences between the means. Therefore, a p-value greater than 0.05 will reveal homogeneity in the samples. As a result, Table 5 shows the difference between the pre-test and the post-test in the study of improvement in basic programming knowledge and the pre-service teacher efficacy. 
Table 5: Study using $t$-student and $p=$ value analysis

\begin{tabular}{lll}
\hline & t test analysis & p-value \\
\hline Efficacy & $-0,200$ & 0,284 \\
\hline
\end{tabular}

Therefore, it is deduced that the students had an improvement in the test scores when following the course planning, although it was not significant $(p=0.284)$. According to these results, the students achieved an improvement in their perception of Efficacy, although it is not significant.

\subsection{RQ3, Mindset}

First a descriptive analysis of the results obtained are shown. Table 6 show the minimum, maximum values, the mean and standard deviation of each test (pre and post.) The results show that there are significant results in the results in the post-test. The minimum, maximum and mean values increase remarkably in the post-test results, although the dispersion increases.

Table 6: Mean and typical deviation in the Mindset

\begin{tabular}{|c|c|c|c|c|}
\hline & \multicolumn{4}{|l|}{$(n=6)$} \\
\hline & Min & Max & Media & SD \\
\hline$\stackrel{\Phi}{2}$ & 3,500 & 4,375 & 3,896 & 0,290 \\
\hline ڤ̆ & 3.000 & 4,375 & 3,771 & 0,567 \\
\hline
\end{tabular}

Figure 4 shows the boxplots of the results in the evaluation in the pre- and post-test. Each box is delimited by the values Q1 (first quartile) and Q3 (third quartile). Each box groups $50 \%$ of the cases, highlighting the median. The lowest and highest value at the end of each diagram correspond to the values that are not less than Q1-1.5 $\cdot(\mathrm{Q} 3-\mathrm{Q} 1)$ and are not greater than Q3 + 1.5 $\cdot(\mathrm{Q} 3-\mathrm{Q} 1)$.

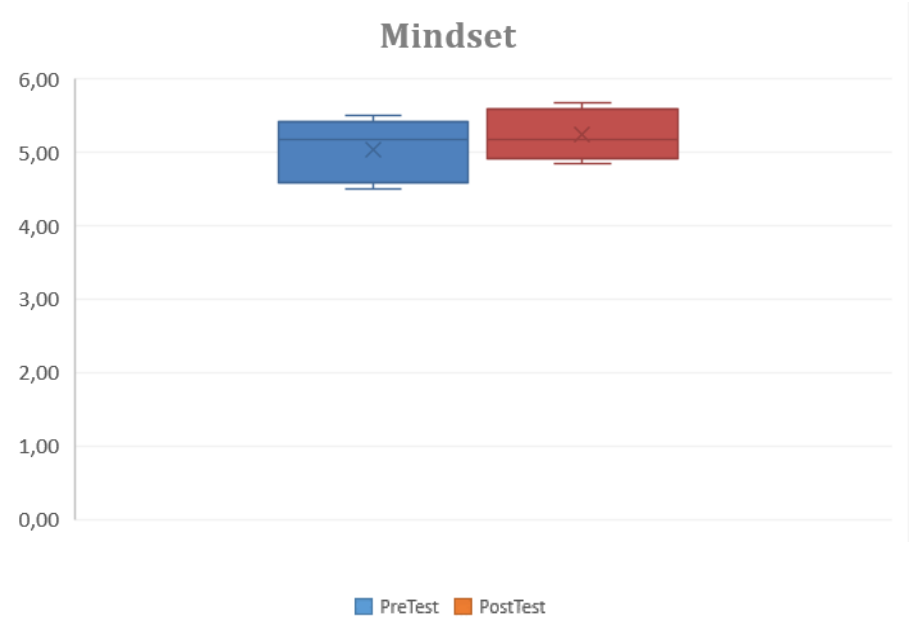

Figure 4. Box-plots for the group of students in pre and post-tests for Mindset 
Comparing the pre-test with the post-test, after analyzing the data, normality can be concluded for the study group (obtaining $p>0.05$ significance using the Shapiro-Wilk test), allowing us to use the tStudent test for paired samples ( $p>0.05$ using bivariate correlation tests). In this test, it has been assumed that the null hypothesis can be established, since there are no differences between the means. Therefore, a p-value greater than 0.05 will reveal homogeneity in the samples. As a result, Table 7 shows the difference between the pre-test and the post-test in the study of improvement in basic programming knowledge. Therefore, it is deduced that the students had an improvement in the test scores when following the course planning, although it was not significant $(p=0.542)$. According to these results, the students achieved an improvement in their perception of Efficacy, although it is not significant.

Table 4: Study using t-student and $p$-value analysis

\begin{tabular}{lll}
\hline & t test analysis & p-value \\
\hline Mindset & 0,125 & 0,542 \\
\hline
\end{tabular}

\subsection{Discussion}

In regard to their perceptions of Computer Science in the Computing Attitudes Survey, adapted from Yadav et al, the pre-service student teachers were asked "What perceptions do you have of computer science as a discipline and as a professional field?" (Yadav et al., 2014). Our research question was concerned if the pre-service teachers could improve their "Computing attitude" by using Code for Math Makers? According to the survey results, the students achieved an improvement, although not statistically significant in their computing attitude survey. The answers submitted eposed the encouraging involvement the pre-service teachers experienced in the $\mathrm{C}^{2} 4 \mathrm{M}^{2}$ programme and their exposure to the Makerspace environment, stating that the experience was "Very relatable to math's and real life"(Pre-service student teacher A reflection) "Interesting and involves a lot of Math's."(Pre-service student teacher B reflection) "Constantly growing, has its own language, interacts with many other disciplines"(Pre-service student teacher F reflection, March 23, 2018)

The second research enquired if the preservice teachers improve their "Efficacy". The teacher efficacy beliefs section of the questionnaire (McInereny, 1997) explored the pre-service teacher belief; when asked which skills used by computer scientists are important for students to learn. The two factors in this measure were firstly the pre-service teachers' beliefs in their personal teaching abilities to embed computational thinking, and secondly their general beliefs about the impact that teachers can have on student understanding of computational thinking. The results indicate that the students achieved an improvement in their perception of Efficacy, although it is not significant. The answers in the prequestionnaire only mention coding, however the results from the post-questionnaire show a greater awareness of problem solving, critical thinking, creativity skills along with communication and the more technical elements such as algorithms and coding. The self-efficacy results demonstrate that the preservice teacher belief in their personal teaching abilities to embed computational thinking improved significantly mindset upon completion of the $\mathrm{C}^{2} 4 \mathrm{M}^{2}$ programme.

The last research question was concerned with the pre-service teacher mindset (Dweck, 2006) improvement through the $\mathrm{C}^{2} 4 \mathrm{M}^{2}$ programme. Again, the results indicate that the students achieved an improvement in mindset, with results showing a positive correlation with growth mindset after their experience at the Makerspace with all students selecting a more positive affirmation on their ability and learning. However, the quantitative results from the questionnaire do not indicate although it is not statistically significant improvement. 
In addition, each of the students were asked to reflect on their learning during the programme. In the qualitative feedback gathered from lesson plan reflections, the evidence of the student learning is evident. For example, the reflections of the lesson emphasized the importance of context in the Makerspace environment "With regards to our individual workshops I feel that overall they went well, and students were interested. If I were to conduct them again, I would highlight more the programming language and how it relates to coding as sometimes the students were slightly confused as to why they were playing it." (Pre-service student teacher $\mathrm{C}$ reflection).

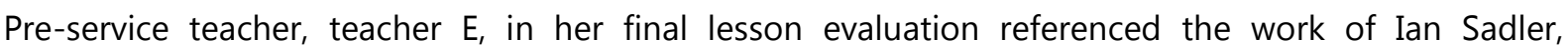
highlighting the increased confidence which the Creative Coding for Math's Makers programme instilled in her: "Over the past few weeks we built the confidence and subject knowledge on the topic of Math's and Coding. This was reflected in our presentation of our final lesson. We learned that in order to successfully teach a topic it is important that you fully understand and are confident about it. Your passion for the subject should be clear through your pedagogical skills. Ian Sadler's 2013 study concludes; "confidence was regularly described in relation to an individual's perceived content and pedagogical knowledge, however, often it was content knowledge that appeared to predominate [...] the main influence of this greater level of confidence upon development was that it was often described in conjunction with taking risks and trying out new ways of teaching" (Sadler, 2013). With this particular topic of Math's and Coding, we as teachers challenged ourselves and took a risk on teaching material that was out of our comfort zone. Thankfully this risk paid off and we can all agree that we enjoyed this experience and will most definitely include it in future teachings." (Pre-service student teacher E reflection).

Lifelong learning of teachers is paramount in helping to promote and advance better-quality educational opportunities and education systems internationally. Indeed, when we speak or write today about teacher education, we more frequently refer to it as characterized by a continuum, acknowledging the potential change and diversity in learning experiences at different points in a teaching career. The results presented from the pre and post questionnaires reflect development in understanding and provide evidence of the importance of the Creative Coding for Math's Makers programme for the pre-service teachers and for the continued development of the teacher as a learner. Fostering a maker-mindset to integrate mathematics and computer science in cross curricular activities, in the transition from insight of computational thinking, to practical design and development - understanding was developed and is reflected in student responses and the results as are presented.

The results from the Computing Attitudes Survey as well as the pre-service teacher reflections would indicate that the design of the $\mathrm{C}^{2} 4 \mathrm{M}^{2}$ fostered a somewhat positive attitude towards computing science for the pre-service teachers. The nature of learning computer programming creates the need to make the relationship between the code and output explicit (Kingsley-Hughes \& Kingsley-Hughes, 2005) but students often lose the psychological connection between the two. The contents, principles, rules and procedures that students learn are organized to make sense of the world and the Makerspace environment facilitated the students to create mental models and to learn. When asked what they would do different next time, one of the pre-service groups responded: "In order to grasp all students interest in the visit to the maker space we feel that we should have completed the research activity prior to their visit as then they may have appreciated it more and been capable of asking questions to the expert when they had the chance" (Pre-service student teacher D reflection).

\section{Conclusion}

Computer science and computational thinking are among the most important areas of learning for young people today. We live now in a highly mediated and networked world - where technology is 
ubiquitous. In this new and emerging, complex global context, Makerspace provides a uniquely creative and constructionist environment in which to develop the critical disciplines of CS and CT for the $21^{\text {st }}$ Century. Crucially, Makerspace affords highly interactive, hands-on education, which enables learners to design, evaluate, iterate and reflect - moving them from being mere consumers of technology to creators with technology.

Firstly and foundationally, $\mathrm{C}^{2} 4 \mathrm{M}^{2}$ has established and illustrated the significant potential of makercentred education as a technology-enhanced learning environment to augment the confidence and competence of teachers in areas cognate to CS education - in this case mathematics - to teach engagingly and effectively in computational thinking. The experience of piloting and developing the "Creative Coding for Math's Makers" project with the pre-service mathematics education teachers has shown us how engaging them in maker-centered approaches to mathematics has enhanced overall their growth mindset, confidence and general capacity as educators, providing them with a whole new set of tools to augment their engagement with their pupils, and potentially to do so drawing powerful crosscurricular links between their 'home' subjects of mathematics and applied mathematics, and the key related domains of computer science and computational thinking.

Furthermore, the data and research reported here strongly illustrate the high-potential of the 'teacheras-learner' as a fruitful methodology for developing and designing teacher PD, especially when computational thinking is not the pre-service teachers' primary subject discipline. Adopting this 'teacheras-learner' approach within makerspace enabled us to support the pre-service teachers' nascent and emerging skills in computer science or computational thinking, which then overall enhanced their capacity to teach these subject areas engagingly and effectively, and is of value for teacher educators and faculty in programme design in initial teacher education.

While further research will be undertaken in the next academic year, the findings of this exploratory, frontier study in the Irish context has shown significant promise and will inform ensuing iterations of $\mathrm{C}^{2} 4 \mathrm{M}^{2}$. Building from the affirming experience of the first deployment reported here, we will now scale and extend the programme, with the aim to inform and shape further the design of teacher professional development, not only for computational thinking education in Ireland, but also potentially for international contexts and educational settings, where computer science and computational thinking are being deployed to enhance young people's and teachers' growth mindset and technological education for the $21^{\text {st }}$ Century.

\section{References}

Barr, V., \& Stephenson, C. (2011). Bringing computational thinking to K-12: What is involved and what is the role of the computer science education community? ACM Inroads, 2(1), 48-54.

Bell, T., Andreae, P., \& Lambert, L. (2010). Computer science in New Zealand high schools. 12th Australasian Conference on Computing Education, Brisbane, Australia.

Brown, N. C., Kölling, M., Crick, T., Peyton Jones, S., Humphreys, S., \& Sentance, S. (2013). Bringing computer science back into schools: Lessons from the UK. 44th ACM Technical Symposium on Computer Science Education (SIGCSE'13). ACM.

Bruner, J. (1996). The process of education. Harvard University Press. 
Cohen, L., Mannion, L., \& Morrison, K. (2000). Research Methods in Education. Routledge Academic Publishers.

Csizmadia, A., Curzon, P., Dorling, M., Humphreys, S., Ng, T., Selby, C., \& Woollard, J. (2015). Computational thinking-A guide for teachers. Computing at School.

Cuny, J., Snyder, L., \& Wing, J. (2010). Demystifying computational thinking for non computer scientists. http://www.cs. cmu.edu/ CompThink/resources/TheLinkWing.pdf

Curzon, P., \& McOwan, P. W. (2017). The power of computational thinking: Games, magic and puzzles to help you become a computational thinker. World Scientific Publishing Company.

DES. (1997). Information and Communication Technologies in Irish Education. Department of Education and Skills.

DES. (2016). Action Plan for Education 2016-2019. Department of Education and Skills.

Doyle, W. (1986). Classroom Organisation and Management. In M. Wittrock (Ed.), Handbook of Research on Teaching (pp. 392-431). Macmillan.

Dweck, C. S. (2006). Mindset. Random House.

Emmer, E., Everston, C., \& Worsham, M. (2003). Classroom Management for Secondary Teachers (6th ed.). Allyn \& Bacon.

Gibson, S., \& Dembo, M. H. (1984). Teacher efficacy: A construct validation. Journal of Educational Psychology, 76(4), 569-582.

Ginsburg, G. P. (1981). Role Playing and Role Performance in Social Psychological Research. In G. N. Gilbert \& P. Abell (Eds.), Accounts and Action (pp. 183-187). Gower.

Hubwieser, P. (2012). Computer science education in secondary schools: The introduction of a new compulsory subject. Transactions in Computing Education, 12(4), 161-164. http://dx.doi.org/10.1145/2382564.2382568.

Kennedy, M. M. (1999). Form and substance in mathematics and science professional development. NISE Brief, 3(2), 1-8.

Kingsley-Hughes, A., \& Kingsley-Hughes, K. (2005). Beginning Programming. Wiley Publishing.

Martin, L. (2015). The Promise of the Maker Movement for Education. Journal of Pre-College Engineering Education Research (J-PEER), 5. doi:10.7771/2157-9288.1099

Mason, J., Burton, L., \& Stacey, K. (2011). Thinking Mathematically. (2nd Ed. ed.): Pearson Higher Ed.

McInereny, V. (1997). Computer Anxiety: Assessment and Treatment. (Doctor of Philosophy). University of Western Sydney Macarthur,

NCCA. (2009). Key Skills Framework. National Council for Curriculum and Assessment. http://www.ncca.ie/en/Curriculum_and_Assessment/Post-

Primary_Education/Senior_Cycle/Key_Skills_Framework/KS_Framework.pdf 
NCCA. (2017). Leaving Certification Computer Science, Draft Specification for consultation. National Council for Curriculum and Assessment. http://ncca.ie/en/Curriculum_and_Assessment/PostPrimary_Education/Senior_Cycle/Consultation/LC-Computer-Science.pdf

Ní Ríordáin, M., \& Hannigan, A. (2009). Out-of-field teaching in post-primary mathematics education: an analysis of the Irish context. National Centre for Excellence in Mathematics and Science Teaching and Learning.

Ní Ríordáin, M., \& Hannigan, A. (2011). Who teaches mathematics at second-level in Ireland? Irish Educational Studies, 30(3), 289-304. https://doi.org/10.1080/03323315.2011.569117

NRC. (2010). Report of a Workshop on the Scope and Nature of Computational Thinking National Research Council. National Academies Press

NRICH. (2019). Thinking Mathematically. https://nrich.maths.org/mathematically

Oates, B. J. (2006). Researching Information Systems and Computing. SAGE Publications Inc.

PISA. (2006). Assessing Scientific, Reading and Mathematical Literacy. A Framework for PISA 2006. PISA (Programme for International Student Assessment). Organisation for Economic Co-operation and Development (OECD)

Prieto-rodriguez, E., \& Berretta, R. (2014). Digital technology teachers' perceptions of computer science: It is not all about programming. Paper presented at the IEEE Frontiers in Education Conference.

Resinck, L. B. (1987). Education and Learning to Think. National Academy Press.

Resnick, M., \& Robinson, K. (2017). Lifelong kindergarten: Cultivating creativity through projects, passion, peers, and play: MIT Press.

Rosen, L. D., Sears, D. C., \& Weil, M. M. (1987). Computerphobia Measurement. A Manual for the Administration and Scoring of Three Instruments: Computer Anxiety Rating Scale (CARS), Attitudes Toward Computers Scale (ATCS) and Computer Thoughts Survey (CTS).

Sarason, I. G. (1991). Anxiety, Self-Preoccupation and Attention. In R. Schwarzer \& R. A. Wicklund (Eds.), Anxiety and Self-Focussed Attention (pp. 9-13): Harwood Academic Publishers.

Schön, D. A. (1991). Educating the Reflective Practitioner. Jossey Bass.

Sneider, C., Stephenson, C., Schafer, B., \& Flick, L. (2014). Computational Thinking in High School Science Classrooms: Exploring the Science "Framework" and NGSS. The Science Teacher, 81(5), 53-59.

Spielberger, C. D. (1975a). Anxiety: State-Trait Process. In C. D. Spielberger \& I. G. Sarason (Eds.), Stress and Anxiety (pp. 115-143). Hemisphere/Wiley.

Spielberger, C. D. (1975b). The Nature and Measurement of Anxiety. In C. D. Spielberger \& R. DiazGuerrero (Eds.), Cross-Cultural Research on Anxiety. Hemisphere/Wiley.

Weintrop, D., Beheshti, E., Horn, M., Orton, K., Jona, K., Trouille, L., \& Wilensky, U. (2016). Defining computational thinking for mathematics and science classrooms. Journal of Science Education and Technology, 25(1), 127-147. https://doi.org/10.1007/s10956-015-9581-5. 
Wing, J. M. (2006). Computational Thinking. Communications of the ACM, 49(3).

Yadav, A., Gretter, S., Good, J., \& McLean, T. (2017). Computational thinking in teacher education. In Emerging research, practice, and policy on computational thinking (pp. 205-220). Springer.

Yadav, A., Mayfield, C., Zhou, N., Hambrusch, S., \& Korb, J. T. (2014). Computational thinking in elementary and secondary teacher education. ACM Transactions on Computing Education, 14(1), 1-16. https://doi.org/10.1145/2576872

\section{Acknowledgement}

Research was funded by Google Ireland Educator Grant, 2017. 